\title{
Screening of Different Genotypes of Chickpea against Gram Pod Borer (Helicoverpa armigera, Hubner)
}

\author{
Lal bahadur Singh ${ }^{1}$, Nikki Bhardwaj ${ }^{2}$, A.K. Bhowmick ${ }^{3}$ and A.K. Panday ${ }^{1}$ \\ ${ }^{1} J N K V V$, Jabalpur (M.P.), India \\ ${ }^{2} R V S K V V$, Gwalior (M.P.), India \\ ${ }^{3}$ Entomology Department, JNKVV, Jabalpur (M.P.), India \\ *Corresponding author
}

\begin{abstract}
A B S T R A C T
Chickpea crop suffers due to the losses caused by various insect pests and diseases. It is attacked by eleven species of insect pests. Among these pests, the pod borer, Helicoverpa armigera (Hubner) (Lepidoptera: Noctuidae) is the most serious insect pest in most of the chickpea growing areas of the world. It damages leaves flowers and pods at different stages of growth and yield losses up to 50 per cent or even more, have been recorded due to the incidence of this pest. Several control measures, especially chemical insecticides, are applied to control this pest. Chemical means of plant protection causes several adverse effects like environment-pollution, pest resurgence, development of resistance in pests against insecticides. To avoid these problems, non-chemical pest control measures need to be promoted. Development and searching of resistant plant material is one of such methods.
\end{abstract}

Keywords

Helicoverpa

armigera,

Chickpea,

Genotypes

Article Info

Accepted:

17 June 2020

Available Online:

10 July 2020

\section{Introduction}

Chickpea (Cicer arietinum L.) is one of the most important leguminous crop and is extensively cultivated in dry and rain-fed areas of the world. Pulses occupy 70.6 million hectares area and contribute 61.5 million tonnes with an average yield of $871 \mathrm{~kg} / \mathrm{ha}$ of produce to the world's total food grain production. In India pulses are grown in about 25.43 million hectare area and produces nearly 17.21 million tonnes (Anonymous, 2017).

Chickpea is the most important pulse crop of India and occupies 9.01 million hectare area with a production of 7.58 million tone accounting for 34.3 per cent and 45.6 per cent 
of total pulse area and production, respectively (Anonymous, 2017).

Being a source of high quality protein chickpea enriches the cereal based diet of the people and improves their nutritional balance (Saxena, 1996). Besides it has medicinal importance, as the germinated gram seeds are recommended to cure scurvy and malic and oxalic acids in green leaves cure intestinal disorders (Singh, 1996).

"Chickpea is a very important component of cropping systems of the dry, rainfed areas, because it can fix 80 to $120 \mathrm{~kg}$ Nitrogen hectare" through symbiotic nitrogen fixation (Papastylanou, 1987).

In Jabalpur district, the total cultivated area under chickpea is 0.059 million ha with about 0.0519 million tonnes of production. Use of insect pest resistant genotypes of chickpea is important in Indian agriculture and little work has been done on this aspect. Resistant genotypes of chickpea to its pod borer would be an ideal approach for integrated pest management (IPM) of Helicoverpa armigera (Hubner).

The use of resistant genotypes is considered as simple, easy, cheap and ideal method of combating pest problems. From farmers' point of view, this can be the most acceptable form of pest control technique. In the past several scientists have made efforts to screen germplasms / genotypes to find resistant sources.

A common limitation is that most of the pest resistant varieties are not high yielding. Breeders are trying to develop high yielding and Fusarium wilt resistant lines of chickpea with resistance to pod borer. Totally resistant and high yielding genotypes of chickpea to pod borer are not currently ready for farmers' use, but are likely to become available in near future.

\section{Materials and Methods}

The experiment was laid out in Randomized Block Design with 50 treatments (genotypes) replicated twice. Plot size was 3 rows of $2 \mathrm{~m}$ length each. Spacing of $30 \mathrm{~cm}$ was maintained between rows and $60 \mathrm{~cm}$ between plots. Seed treatment with the Rhizobium culture @ $5 \mathrm{~g} / \mathrm{kg}$ seed was used for enhancing nodulation. The crop was sown on December 3, 2017 using standard agronomic practices.

The larval population data were subjected to statistical analysis after transformation ( $\mathrm{x}$ $+0.5)$, while data in percentages were transformed to their angular values.

\section{Results and Discussion}

Total fifty genotypes of chickpea were screened against $H$. armigera to know their response against these genotypes, the damage observations were recorded at flowering and pod formation stages by counting the number of larvae/plant.

\section{Per cent pod damage}

The pod damage revealed significant differences among the genotypes under investigation ranging from 5.41 to 24.38 per cent. The minimum pod damage was observed in genotypes E-106 (5.41\%) followed by E-156 (5.67\%), E-153 (6.49\%), E-161 (6.52\%) and E-103 (6.81\%). Significantly highest per cent pod damage was recorded in genotype E-80 (24.38\%) followed by E-33 (18.13\%) and E-104 (17.89\%), E-154 (17.50). The rest of genotypes showed intermediate pod damage ranged from 6.49 to 14.42 per cent.

\section{Seed yield (kg/ha)}

The seed yield in different genotypes ranged from 1408 to $2291 \mathrm{~kg} / \mathrm{ha}$. The highest seed 
yield of $2291 \mathrm{~kg} / \mathrm{ha}$ was recorded in the genotype E-161 followed by the genotypes E105, E-106, E-109, E-111, E-117, E-118, E77, E-120, E-152, E-153, E-156, E-79, E-161, E-163, E-164, E-28, E-31 and E-34 ranged from 2000 to $2258 \mathrm{~kg} / \mathrm{ha}$. The lowest seed yield was observed in genotype E-158 (1408 $\mathrm{kg} / \mathrm{ha}$ ) followed by E-104 (1533 kg/ha), E154 (1591 kg/ha) and E-108 (1691 kg/ha). Rest of the genotypes recorded intermediate seed yield (ranged from 1700 to $2000 \mathrm{~kg} / \mathrm{ha}$ ).

At flowering stage the larval incidence of $H$. armigera was low, and ranged from 0.20 to 1.10 larvae/plant. The lowest larval population was recorded (0.20 larvae/plant) in genotypes E-31, E-29, E-160, E-162, E-164, E-151, E-152, E-154 and E-155 while highest larval population was recorded $(1.10$ larvae/plant) in genotypes ICC-3137 and L550. The present findings are supported by the findings of Ogenga et al., (1994) who reported lowest larval population of $H$. armigera on chickpea cultivars ICC- 506 (0.22 larvae/plant), while Reddy et al., (1996) reported chickpea varieties Pusa 261, BG374, BG-386 as the least susceptible. Yelshetty et al., (1996) reported genotypes BJ-256 have the lowest pest density under field condition.

At pod formation stage there was a slight increase in larval population in all the genotypes. However, there were significant difference in larval population in all the genotypes, observed. The larval population ranged from 0.50 to 2.30 larvae/plant.

The genotypes E-160 recorded the lowest larval population (0.50 larvae/plant) followed by E-105, E-113, E-114 (0.90 larvae/plant) and E-30 (0.80 larvae/plant). The highest larval population (2.30 larvae/plant) was recorded in genotypes L-550 and E-68 followed by ICC-3137 and E-102 (2.10 larvae/plant).
The present findings are supported by the findings of Bhatnager and Rao (1997) who reported that chickpea genotypes JG-897, JG322 and JG-394 exhibited good resistance against $H$. armigera under rainfed conditions. Das and Katariya (1998) also reported lowest pod damage $(2.7 \%)$ in variety JG-74. The pod damage revealed significant differences among the genotypes under investigation ranging from 5.41 to 24.38 per cent. The minimum pod damage was observed in genotypes E-106 (5.41\%) followed by E-156 (5.67\%) and E-103 (6.81\%). Significantly highest per cent pod damage was recorded in genotype E-80 (24.38\%).

The seed yield in different genotypes ranged from 1408 to $2291 \mathrm{~kg} / \mathrm{ha}$. The highest seed yield of $2291 \mathrm{~kg} / \mathrm{ha}$ was recorded in the genotype E-161 and the lowest seed yield was observed in genotype E-158 (1408 kg/ha) followed by E-104 (1533 kg/ha) and E-108 $(1691 \mathrm{~kg} / \mathrm{ha})$. The present findings are inconformity with the findings of Bhatt and Patel (2001) and Mandal (2003) they evaluated the chickpea cultivars against $H$. armigera on yield and per cent pod damage and reported that both the parameters are adopted to produce an illusive picture on resistance. Similarly, Gowda et al., (2005), Parsai (2005), Wakil et al., (2005b), Chandrakar et al., (2006), Gowda et al., (2007), Narayanamma et al., (2007), Kooner and Cheema (2008), Cheema et al., (2010). Chaturvedi and Ali (2010) have considered pod damage and yield parameters as the factors for determining resistance against $H$. armigera in different experiments.

\section{References}

Anonymous. 2017. FAO Statistical data. http://www.faostat.fao.org.in

Bhatnagar A and Rao SS. 1997. Screening of chickpea against Helicoverpa armigera Hubner under rainfed conditions in the Bastar region of Madhya Pradesh, India. 
International Chickpea and Pigeon pea Newsletter 4: 24-26.

Bhatt NJ and Patel RK. 2001. Screening of chickpea cultivars for their resistance to gram pod borer, Helicoverpa armigera, (Hubner). Indian Journal of Entomology 63(3): 277-280.

Chandraker MK Shrivastava SK and Arvind Kumar. 2006. Field screening of resistant varieties of chickpea against gram pod borer, (Helicoverpa armigera Hubner). Environment and Ecology 24(3): 728-729.

Chaturvedi SK and Ali M.2010. Development of early maturing chickpea varieties for diversification of rice-wheat cropping system. Indian Institute of Pulses Research 50(1): 248-253.

Cheema HK, Singh R, Taggar GK, Sandhu JS and Kooner BS. 2010. Screening of chickpea genotypes for resistance against gram pod borer, (Helicoverpa armigera Hubner) under field conditions Journal of Research, Punjab Agricultural University 47: 1-2

Das SB and Kataria VP 1999. Relative susceptibility of chickpea gen otypes against Helicoverpa armigera (Hubner). Insect environment 5(1):39.

Gowda DKS, Sharanabasappa and Halle D. 2005. Screening of resistant chickpea genotypes for Helicoverpa armigera (Huner.) Karnataka Journal of agricultural Sciences. 18(4): 1107-1108.

Gowda DKS, Sharanabasappa and Halle D. 2007. Screening of resistant chickpea genotype for Helicoverpa armigera (Hubner). Karnataka Journal of Agricultural Sciences. 18(4):1107-1108.

Kooner BS and Cheema HK. 2008. Reaction of chickpea genotypes against gram pod borer,
(Helicoverpa armigera Hubner).Journal of Food Legumes. 21(3):185-186.

Mandal SMA. 2003. Screening of some chickpea genotypes against Helicoverpa armigera (Hubner). Environment and Ecology. 21 (1):240-241.

Ogenga NW, Latigo JE, Obuo and orolon P. 1994. Infestation and pod damage by Helicoverpa armigera (Hubner) on chickpea. International Jonral pest Management 40(3):245-248

Papastylanou , 1987. Effect of preceding legume on cereal grain and nitrogen yield. Journal of Agricultural Science 108(8):623-626.

Raddy PV, Singh Y, Singh KM and Singh SP. 1996. Chickpea varietal response to pod borer (Helicoverpa armigera, Hubner) crop. Indian Journal of Entomology. 59(4):359-361.

Saxena, M. C. 1996 Chickpea in the WANA region: An overview: Adaptation of chickpea in the West Asia and North Africa Region, ICRISAT, Patancheru, India, pp.36.

Singh S. S. 1996 Handbook of Agricultural Sciences. 1st Edi., Kalyani Publishers, New Delhi, India pp.824.

Wakil W, Ashfaq M, Mansoor-ul-Hasan and Javed A. 2005. Evaluation of different chickpea (Cicer arietinum L.) genotypes against Helicoverpa armigera (Hubner.) in Rawalpindi, Pakistant. Pakistan Entomology 27(1):41-45

Yelshetty S, Kolokal YK, Sharntoppamaar NB and Lingappa S. 1996. Screening of chickpea for resistance to pod borer in Karnataka, India. International Chickpea Newsletter 3:41-43.

\section{How to cite this article:}

Lal bahadur Singh, Nikki Bhardwaj, A.K. Bhowmick and Panday, A.K. 2020. Screening of Different Genotypes of Chickpea against Gram Pod Borer (Helicoverpa armigera, Hubner). Int.J.Curr.Microbiol.App.Sci. 9(07): 1811-1814. doi: https://doi.org/10.20546/ijcmas.2020.907.207 